\title{
Gender Impacts of Taxation: A Review of the Literature
}

For this paper, we reviewed more than 67 studies that explored various dimensions of gender and taxation. These studies are summarised in Table 5.1. Most studies focus on a single country; far fewer provide comparative analyses of the gender dimensions of tax policy. The majority of the studies examine the gender dimensions of taxation in the industrialised countries, although there is a growing body of work on the gender dimensions of tax policy in countries like South Africa, Vietnam and Chile.

In the industrialised country literature, the topics covered most frequently are the impact of personal income taxes on labour supply, gender biases in systems of joint versus individual taxation and gender biases in social security taxes. The developing country studies focus on gender biases of indirect taxes and the gender dimensions of user fees.

\subsection{Summary of Possible Gender Bias by Tax: Explicit and Implicit Bias}

Because all tax systems evolve over time and reflect prevailing social and cultural norms which often discriminate against women, tax systems also contain gender bias. Stotsky (1997a) presents a useful conceptual framework for understanding this bias both in its explicit and implicit forms. Table 5.2 shows the possible types of gender bias for four principal types of taxes: personal income tax; corporate income tax; commodity taxes; and trade taxes.

Explicit bias is found in specific provisions of the law that treat men and women differently. Explicit biases are relatively easy to identify since they depend largely on the language used in the tax code or tax regulations. They are more common in personal income tax arrangements than in other forms of taxation in both developed and developing countries. Implicit gender bias - different impacts on men and women because of different social arrangements and economic behaviour - may be found in personal income tax systems if they have joint filing requirements that tax secondaryearner incomes (primarily women's) at a higher marginal tax rate, thus affecting women's labour supply and other decisions. Implicit bias may also be found in other taxes such as consumption taxes, trade taxes and corporate taxes to the extent that they impact on female and male taxpayers differently, and in the way that payments are linked to the receipts of benefits under social insurance programmes. 


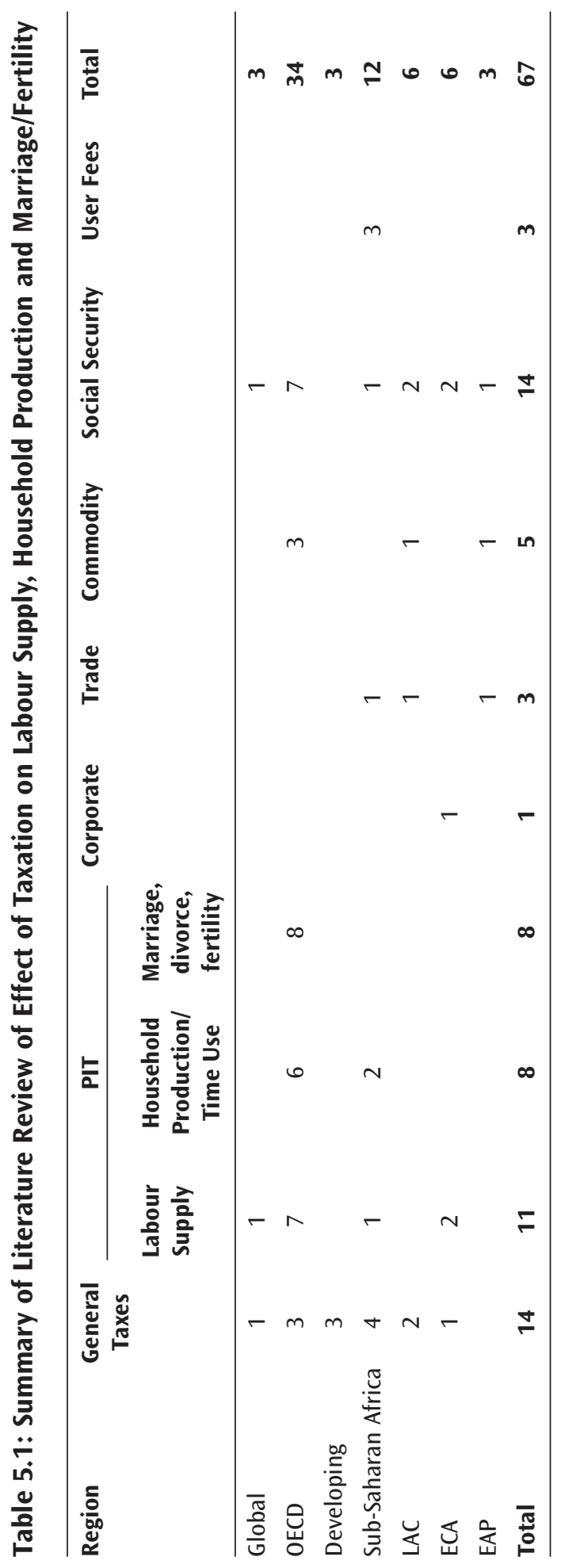


Table 5.2: Types of Gender Bias by Tax: Explicit and Implicit Bias

$\begin{array}{lcc}\text { Explicit } & \text { Implicit } & \begin{array}{c}\text { Indirect/ } \\ \text { Ambiguous Effect }\end{array}\end{array}$

\section{Personal Income Tax}

A. Separate Filing

i. Allocation of non-labour and/or family business income

ii. Allocation of tax preferences

iii. Rate structure

B. Joint Filing

i. Allocation of tax preferences $\quad \mathrm{X}$

ii. Responsibility for filing $X$

iii. 'Marriage tax' (marginal rates)

$\mathrm{X}$

\begin{tabular}{lll}
\hline 2. Corporate Income Tax & & $\mathrm{X}$ \\
\hline 3. Commodity Taxes & $\mathrm{X}$ & $\mathrm{X}$ \\
A. VAT or broad-based sales & $\mathrm{X}$ & \\
B. Excise or selective sales & & $\mathrm{X}$ \\
\hline 4. Trade Taxes & $\mathrm{X}$ & \\
A. Import duties & $\mathrm{X}$ & \\
B. Export taxes & \\
\hline
\end{tabular}

Source: Stotsky, 1997

\subsection{A Hypothetical Gender-Tax Typology}

Table 5.3 is an example of a possible approach to gender analysis of taxation. The table presents a hypothetical gender-tax typology. The typology classifies countries according to their level of income: low, low-middle, upper-middle, and high income. The table profiles the primary economic activities of women in these countries and matches these to the principal types of taxes that affect women engaged in these activities. For each tax type, the most important potential bias, e.g. implicit or explicit, is described. Finally, the table includes a column with hypothetical priority recommendations for improving the gender equity of tax policy. Note, however, that the information in Table 5.3 is hypothetical and not derived from information on actual countries at these levels

The remainder of this section explores the various gender biases that may exist in different types of taxes. It summarises the findings of studies exploring the effects of personal income tax on female employment, household production and time use, and fertility in developed countries and draws lessons for developing countries. Although the literature from developing countries is not as extensive as the studies based on developed country data, the latter do provide background for the gender analysis of taxation in developing countries. The literature from developed countries can also provide important lessons about how gender bias can be identified and corrected in current tax systems, and possibly avoided in future tax policy decisions. 


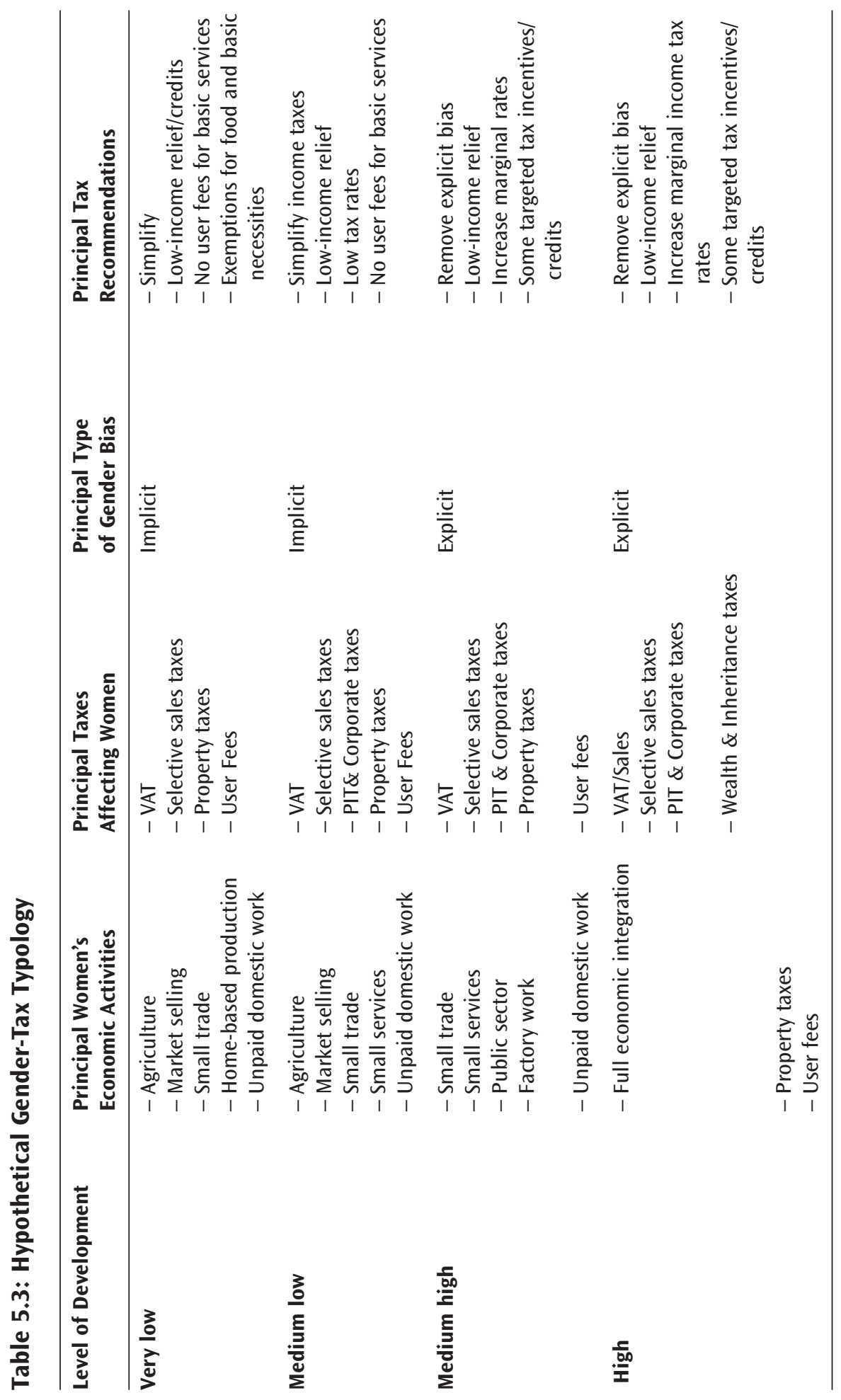


The sections below are organised by principal taxes. We begin with the personal income tax. The personal income tax constitutes a smaller share of total tax revenue in low-income countries than in developed countries but Table 3.3 shows that this share is as high as 20 per cent in Malawi, for example, and the share is likely to grow with development (Table 3.2). And finally, it is the tax whose structure can most easily address (gender) equity goals, so it is especially important for a gender analysis of taxation.

\subsection{Personal Income Taxes}

In developed countries, the personal income tax (PIT) raises desired revenues from a broad tax base with reasonably low rates. Its base of wage and non-wage income grows with the economy and keeps up with inflation. In countries with high literacy rates, the PIT is also fairly easy to administer. It can be used to address equity and redistribution goals through a progressive tax rate structure, with marginal rates which impose a lighter burden (or guarantee a minimum income) at the lower end of the income scale, and a gradually greater one at higher ends, following principals of vertical equity and ability to pay.

In developing countries, however, the PIT is often a more limited tax mechanism for several reasons: a) high rates of poverty mean that the personal income tax base is weak and narrow, and there is a greater need for redistribution; b) steep progressivity in marginal tax rates may unfairly burden those employed in the formal sector and/or create incentives for tax evasion and corruption by a small wealthy elite; c) high rates of illiteracy and a weak civil service infrastructure make the tax difficult to administer and enforce.

\subsubsection{Gender Bias in Personal Income Taxes}

The review of the literature suggests that most personal income tax systems are not gender neutral. Even in countries which have reformed their PITs to be more gender equitable, a number of thorny issues remain.

The appropriate unit for personal income taxes has been a subject of some debate in the economics literature (see Nelson, 1996 for a summary). The tax unit is the unit over which the income tax base is aggregated. In principle, the definition of the unit can vary for different types of income, although in practice the assessment unit is usually either the individual or a married couple. Some developing countries have a tax unit based on the extended family that is the typical social unit. In some countries with large Hindu populations, as in India, the 'Hindu undivided family' is the filing unit (Stotsky, 1997a). The Hindu undivided family consists of all male Hindus descended in the male line from a common ancestor, their wives and unmarried daughters; responsibility for filing for the family is vested in the eldest male member. Several countries have provisions in their tax code for multiple wives, and Nigeria's 
tax code provides more generous tax treatment for the first wife than for succeeding wives.

Julie Nelson (1996) questions the definition of the 'proper' tax-paying unit and finds that both household and individual definitions are problematic. She argues that 'the notion of the household as a unit presupposes that households can be uniquely identified', which implies, for example, that information on different types of household must be available. Moreover, she suggests that equity principles (discussed above) dictate that levels of household wellbeing must also be well-defined; as noted earlier, this is difficult to do in practice. ${ }^{16}$ The notion of the individual as the unit, on the other hand, tends to focus attention on adult earners as the only tax-relevant human beings, ignoring issues of dependency and social relationships. Nelson looks for a middle ground, suggesting that the tax code should define a unit of taxation as an individual earner plus his or her dependents, i.e. those persons who are unable to support themselves for reasons such as youth, old age or chronic disability.

Although discussion of the details of Nelson's proposal is beyond the scope of this paper, two observations are worth noting: her proposal is marriage neutral, and it imposes a lighter tax burden on the two-earner couple than the one-earner household. If countries are to adopt this approach, many questions, such as the treatment of property income, how to allocate child exemptions and the allocation of social security taxes and benefits will need to be worked out in the tax code. One possible line of approach is the calculation of an 'adult consumption equivalent', which includes both working adults and their dependents.

There are two types of personal income taxes - schedular and global. A schedular tax calculates liability on each source of income, while global taxes apply a single rate schedule to aggregated income. Schedular taxes are typically found in developing countries, especially those where tax administration capacities are weak. Global income taxes are typically found in industrialised countries and increasingly in developing countries. Schedular regimes may contain implicit gender bias, insofar as they include elements, such as deductions and credits, based on the personal characteristics of the taxpayer (Stotsky, 1997a).

Global income taxes, which are assessed on either an individual or a family basis, contain a number of explicit gender biases. Under an individual filing system, married individuals file a separate return based on their own labour earnings. The allocation of non-labour earnings and exemptions or deductions for children and other purposes is determined by the country's tax laws and can be a source of gender bias. Most developing countries require individual filing for at least some sources of income. Joint filing systems with progressive marginal rate schedules also contain explicit gender bias in the allocation of tax preferences (i.e. to only one spouse) or in filing rules. Most industrialised countries had joint filing at one time, although many have moved to individual filing in order to reduce gender discrimination. 


\subsubsection{Gender Implications of PIT Individual Filing}

Stotsky (1997a) identifies three types of potential gender bias in systems that permit individual filing: the allocation of non-labour or business income; the allocation of tax preferences or exemptions; and tax rates.

In income tax systems with individual filing, wage income is attributed to the worker, but the attribution of non-wage income in a household is not so simple. Tax codes allocate this income in a variety of ways, including attributing it to the higher earner, allocating the income equally between partners, allowing couples to make the decision for how to allocate the income or attributing the income to the spouse who possesses legal ownership of the property. Many countries' tax codes allocate all nonwage income to the husband whether or not this is true in practice: this is the case for some countries in Latin America, Asia and Africa which allow women to pay tax on their labour income but attribute all non-labour income to the husband.

In many parts of the world, family business income is also attributed to the husband regardless of the spouse's role in the business: this is the case in Tanzania, for instance. Often the rationale is to prevent tax avoidance. However, there are administrative solutions to this problem that would be more gender equitable.

A second form of gender bias occurs in the allocation of exemptions. Often, countries give exemptions or deductions for a variety of purposes, including for dependent children and non-working spouses. These exemptions must be allocated between spouses or parents in some way, and rules differ widely across countries. In Jordan, for instance, if husbands and wives file separately, some deductions are only available to the husband and not to his wife. In Zimbabwe, married men with non-working wives are entitled to a special credit but there is no such provision for married women with non-working husbands.

A third form of gender bias can be found in a country's tax rate structure. Countries may levy different tax rates on men and women, with a higher rate being applied to married women than to married men, as was done in South Africa until 1995 and still happens, for example, in several other countries in the Middle East. This will be discussed further below.

\subsubsection{Gender Implications of PIT Joint Filing}

In the US and in most countries in Europe which tax the household, the income obtained by all family members is added together, resulting in a higher marginal rate than the one which would be paid if an individual filed alone (de Villota and Ferrari, 2001). The literature review showed that higher marginal rates deter women from entering the paid labour market and keep them in part-time jobs. According to Sainsbury (1996), joint taxation stems from an ideology favouring the traditional family where the husband is identified as head of the family and financial supporter of the household, and the wife devotes her time exclusively to looking after children and 
domestic work. High marginal rates still exist in many PIT systems despite more gender-equitable mechanisms such as income splitting, the family ratio, a joint rate with lower tax levels for families than for single persons without dependents or deductions for accrued tax obligations.

Beyond high marginal tax rates for secondary earners, Stotsky (1997b) identifies two other forms of explicit gender bias in systems with joint filing. One form is making tax preferences available only to the husband, for instance, an allowance for married men if he supports the household but not an allowance for married women. Many countries in the Middle East and North Africa allow men to claim deductions for children on their income. These deductions may only be taken on women's income if she is the sole breadwinner, if her husband agrees (Jordan), or if the father is dead or handicapped (Lebanon). The rationale behind these rules is that a family should only be allowed to take the deduction once, even if both the father and mother work. A second form of bias occurs in countries that require jointly filed returns to be submitted in the name of the husband; consequently wives have no separate existence as taxpayers. This was the case in Britain until 1990; Switzerland continues the practice today.

\subsubsection{Impact of PIT on Married Women's Labour Supply ${ }^{17}$}

As noted above, systems of joint filing with a progressive marginal rate schedule often discourage secondary earners because the tax on the secondary income starts at the highest marginal rate of the 'primary' earner. This is known as the marriage penalty.

The public finance literature on the marriage penalty in the US and in European countries concludes that the principal impact of high marginal rates has been on wives, who generally earn less than their husbands and are in effect taxed at their husband's marginal rate (Bartlett, 1998). Thus, wives generally receive less after-tax income on each dollar they earn than their husbands, which is a significant disincentive to married women to enter the paid labour force. The disincentive effects of high marginal tax rates on married women's labour supply are further exacerbated by their responsibilities in the unpaid care economy during their reproductive years. ${ }^{18}$

The empirical literature also shows that the labour supply elasticity of married women, who are often assumed to be secondary earners, is greater than the labour supply response of married men. The 1981 US Tax Act reduced the marriage penalty by instituting a secondary-earner deduction. Feenberg and Rosen (1995) found that following the Act married women's participation in the labour market expanded by almost enough to pay for the revenue loss caused by the deduction. Eissa's (1995b) analysis of the 1986 US Tax Reform Act, which lowered the top marginal tax rate from 50 per cent to 28 per cent, similarly found that married women responded more strongly to the increased work incentive than men did. A Norwegian study found an increase in the labour supply of married women with equalised tax schedules across 
marital status (Aaberge et al., 1989). The implication of this research is that to minimise the 'deadweight loss' of the income tax, everything else being equal, married women should be taxed at a lower rate than other workers.

However, it is important to note that the conventional literature examining the impact of taxation on labour supply assumes that the alternative to paid work is leisure, whereas most women allocate their time to home production and to leisure. The findings of this literature are most certainly incorrect: when household production is incorporated into the analysis, the labour supply response of married women is seriously underestimated (Apps, 2002b). In addition, purchased childcare is considered to be a cost only when the mother seeks paid employment: the time cost of childcare provided by mothers is assumed to be zero. Analysing data from European countries, Apps (2002a) finds a strong positive effect of childcare subsidies offered through the tax system on female labour supply and on fertility because market childcare and mother-provided care are close substitutes. Further research is needed to show the relevance of this effect for women in different income classes in countries at different levels of economic development.

Finally, tax and welfare policies that ignore household production can lead to an increase in inequality across and within households and impose significant efficiency losses by reinforcing gender roles (Apps and Rees, 1999a). We turn to this issue next.

\subsubsection{Impact of PIT on Time Use and Household Production}

Models of the effect of taxes and transfers must rely implicitly or explicitly on some theory of how households function. The traditional view, pioneered by Gary Becker in 1974 and 1981, argues that men specialise in market work and women specialise in household production. Other things being equal, labour in household production is subject to diminishing returns - if the value of household capital and technology remains constant, the value of goods and services produced by an additional unit of labour begins to decline at some point. Both men and women making decisions about time allocation devote their labour to household production as long as the value of hourly product from that production is greater than the market wage. Women therefore work longer hours in the household than men and fewer hours in the market. Many studies of the impact of tax and transfer in developed countries rely on this theory of the household.

Many scholars have criticised this view and its use in tax analysis. Apps (2002b) and Apps and Rees (1999a, b and c), for instance, point out that specialisation in domestic production may result either from higher productivity or from lower productivity in household work. As Apps (2002b) says, 'High productivity in domestic production implies a low implicit price and a higher demand for domestic output. The higher the productivity, the less time is required to produce a given domestic output and more time is available for market labour supply. The net effect depends on the 
price elasticity of demand for domestic output in relation to domestic productivity.' Thus, tax policy analysis that is based on average household income may be misleading because it misrepresents the true distribution of living standards. ${ }^{19}$

As noted earlier, one measure of tax fairness is ability to pay. Julie Nelson (1996) makes the point that 'if household services are counted as income, the ability to pay of an earner and homemaker couple with a given money income will be higher than that of a household in which earning the same money income requires that both adults work outside of the home'. (This is similar to the example we discussed in Section 4.) The two-earner couple has less time for leisure and needs more money to pay for market goods to replace those formerly provided at home. Nelson argues that households with an earner and homemaker 'should also be compared, in terms of household services, to the household of an earner and a child or other dependent (based on age, disability or illness) who have need for care'. She notes that the ultimate losers in systems where domestic output is 'free' are lone parents, unless they receive special help in other ways.

Because the norm of marriage and the nuclear family as well as the allocation of women's time between market work, unpaid labour and leisure in developing countries differs significantly from that of women in developed countries, the relevance of the European and US literature is questionable. More research is necessary to understand the impact of tax and welfare systems on women's time allocation and unpaid work in developing countries. Nonetheless, one lesson from the developing country literature stands out. Basing the design of a personal tax and transfer system on combined family income, while ignoring women's unpaid work in the care economy, is problematic. ${ }^{20}$ This type of system can widen gender inequality and increase the gap between rich and poor.

\subsubsection{Impact of PIT on Fertility}

Concern about population decline has induced some governments to adopt explicitly pro-natalist policies: these countries have included Canada, Singapore, France, East Germany and Hungary. At the other extreme, China has instituted economic incentives to reduce fertility. Given that most developing countries are trying to reduce fertility, the effects of tax incentives on birth rates in these countries remains unclear and there is currently no literature on this issue.

A study from the US by Whittington et al. (1990) examined the impact of the personal exemption in the US tax code on fertility. Using fertility data from 1913 to 1984 to ascertain whether changes in the exemption level impacted on fertility rates, they found that the personal exemption had a positive and significant effect on the national birth rate. They note that increases in the personal exemption served as effective decreases in the costs of raising children. Although the elasticity of the birth rate with respect to the exemption was not large, this study suggests that countries can influence to a degree the fertility decisions of its citizens through changes in tax 
policies. But putting a tax on additional children would be unfair to the poor, who tend to have more children.

\subsection{Payroll Taxes}

Payroll taxes are an alternative form of income tax. They are deducted at source from the wages of employees, often with a matching portion paid by the employer, based on total payroll. Developed countries use payroll taxes primarily to fund social security systems. Many developing countries use payroll taxes as a source of general revenue because they are relatively easy to administer and collect, as well as to fund social security systems. However, a payroll tax generally imposes a greater tax burden on the poor than the PIT because: a) it falls on a much narrower base than the PIT - only on the wage portion of income and only on the wages of those employed in businesses over a certain size which are required to keep formal accounting books; b) because of the narrower base, it requires much higher tax rates than the PIT in order to raise the same amount of revenue; c) the employer may be able to recoup all or part of taxes paid by reducing wages to workers or increasing prices to consumers, causing an additional burden on the poor; and (d) it falls on all employees, whereas low-income workers in these companies may be exempt from the personal income tax.

Generally, people pay taxes on their income when they actually earn it. However, an exception is made with respect to taxation of income contributed to retirement funds and pensions: tax is paid when the retirement or pension benefits are actually received after the worker retires. The intention of the tax deferral is to encourage individuals to save for retirement. However, its result is regressive because the deferral is only available to people with sufficient income to be in the income tax system and because, within that group, those who earn more and are taxed at higher marginal rates benefit more from deferral than those who earn less and pay lower marginal rates.

In the past ten years, countries with defined 'pay-as-you-go' (PAYG) public pension systems have been moving to privatised defined contribution systems. Pension reforms are well underway in Latin America and the transition countries in Eastern Europe. In these countries, a multi-pillar structure is developing. The new structure consists of two mandatory pillars. One pillar handles the funded accounts that people are required by government to have. This pillar is usually defined contribution instead of defined benefit. The benefits are funded rather than 'pay-as-you-go' and the funds are privately managed. The second pillar is a publicly managed tax-financed arrangement designed to provide a social safety net to protect low wage earners. ${ }^{21}$

There are several rationales for defined contribution plans. First, they are seen to reduce the incentive for evasion, which is a problem in many countries. James (1998) notes that, in some countries, between 20-30 per cent of the covered labour force evades taxes. She argues that smaller taxes and closer links between benefits and 
contributions reduce the incentive for evasion. Second, defined contribution plans are structured to discourage early retirement, which gives the system more financial sustainability. Third, defined contribution plans avoid large payroll tax increases which may be necessary over time as a country's population ages.

Critics do not agree that privatising pensions is the best way to raise revenues and support workers in their old age. Baker and Kar (2002) contend that it is also possible to raise the return on defined contribution systems by adding more government funds which is, in effect, what private accounts do: they increase government payments to support pension systems, contributing general revenue (and imposing a tax on capital income) but they do it through changing relative prices. Apps and Rees (2002) and others also show that the switch from PAYG to funded pension systems in developed countries is not a solution to the problems raised by increasing aged-dependency ratios and declining fertility in those countries.

\subsubsection{Gender Bias in Payroll Taxes}

Our review of the literature found several studies on social security taxes in the developed countries. ${ }^{22} \mathrm{~A}$ few recent studies have also explored the effect of pension reforms in Latin America and Eastern Europe on women and men.

Three main factors explain gender gaps in private pension coverage: women's household responsibilities, women's work patterns and pension design. Because pension entitlements are predominantly through work, women's responsibilities for unpaid care work, as well as their predominance in informal employment and seasonal and part-time jobs, all restrict their access to the private pension sector. Private pension coverage is more extensive in larger firms and in those industries requiring a skilled, stable and full-time labour force. Pension design is the third factor, and many pension systems contain both implicit and explicit gender bias. ${ }^{23}$

Several studies in our review examine the gender impact of pension reforms in Latin America. Baker and Kar (2002) note in their survey of Latin American pension reform that reform efforts have included raising the retirement age to the same level for both sexes. While this is a reasonable policy, it means that women workers will experience a larger reduction in benefits than men. The impact of this benefit reduction is compounded by the shift to defined contribution plans which the authors claim are less favourable to women for two reasons. First, since women generally earn lower wages than men and spend fewer years in formal employment, they are likely to accumulate much less in individual accounts than men. Second, the structure of the benefit payment hurts women. The benefit payment from a defined benefit plan is gender blind, with a worker's benefit depending on his or her contributions. However, the payments from most defined contribution plans are based on gender-specific life expectancies. This means that a woman who retires at a particular age receives a smaller benefit than a man retiring at the same age with an identical accumulation 
because she has longer life expectancy. The combination of gender-specific annuities and the lower accumulations that women are likely to have could lead to reductions in benefits for many older women.

In contrast to these claims, James et al. (2002) undertook a cross-country empirical analysis of the gender impact of pension reforms in Chile, Argentina and Mexico. They found that women generally accumulate retirement funds and own-annuities that are only 30-40 per cent those of men from the defined contribution pillar of the multi-pillar systems. However, they note that the effect seems to have been mitigated by targeting the new public pillars toward lower wage earners, many of whom are women, and by restrictions on pay-out provisions, including joint annuity requirements, which redistribute income from husbands to wives within households. They claim that as a result of this 'total lifetime retirement benefits for women reach 60-80 per cent of those for men; for "full-career" women, they equal or exceed benefits of men'.

Cox Edwards (2001) provides a detailed analysis of pension reform in Chile. She finds that it 'increased women's incentives to participate in the labour market, to save, and to use the social security system as a channel for their savings ... Under the new system's rules, there is no minimum level of contributions to obtain a pension; contributions at a young age get an increased weight via compound interest; and widows can keep their own pension in addition to their widow's pension. These three characteristics raised the marginal benefit of own contributions for working women relative to what the old system offered. ${ }^{24}$

Because the specifics of pension reform vary across countries and there are too few studies to draw clear conclusions, further research is necessary to determine whether women are better off in defined contribution plans. Public pension schemes which can provide insurance and redistribution on a wider scale than personal pensions may be an important supplement to defined contribution plans in countries undergoing reform (which are largely middle income), or be a better alternative for women in countries at low levels of income, where informal employment and widespread poverty co-exist.

\subsection{Commodity Taxes (VAT, Sales, Excise)}

Since the time of J.S. Mill and Alfred Marshall, economists have argued that taxation should be imposed on consumption, not income, in order to avoid the disincentives to paid labour, investment and savings which income taxes create. However, commodity taxes impose a greater tax burden on the poor than on the rich because the poor spend most or all of their income on basic consumption. Commodity taxes also alter the relative prices of taxed and untaxed goods and thus alter individual and household decisions about consumption, and business decisions about investment and produc- 
tion. Commodity taxes generally seek to apply the lowest rate possible to the broadest possible tax base, with minimal exemptions.

The value-added tax is a commodity tax that has become the predominant form of commodity taxation in many developed and developing countries. ${ }^{25}$ By April 2001, 123 countries had some form of VAT; 27 countries in sub-Saharan Africa had a VAT, compared to only four in 1989 (Ebrill et al., 2001, Table 1.1). ${ }^{26}$ The most populous countries without a central VAT are India and the US. Developing countries that have adopted a VAT have relatively higher GDP per capita and rely somewhat less on international trade than countries without a VAT.

The incidence of VAT and other broad-based consumption taxes falls in principle on the final consumer. Any preferential treatment, as a result, is usually given to the final consumer. Typically, preferential treatment is applied to goods and services that are considered necessities, such as food and medical care, so as to minimise the burden on the poor, and to goods and services that for administrative reasons are difficult to tax, such as financial services (see Box 5.2). Tax preferences can also apply to certain purchasers or producers, such as non-profit institutions or the government. Most countries with a VAT exempt agriculture, because a large share of the agricultural sector is informal and most of the poor are active in that sector (Le, 2003).

\section{Box 5.2: Case Study on Trinidad and Tobago}

Trinidad and Tobago incorporated in its VAT regime numerous zero and reduced rates and exemptions that were intended to make the system less regressive than the previous purchase tax. Zero rates were granted to basic goods, in addition to exports, and exemptions included health-related services, most of education, rental of residential property, and bus and postal services. Even with these poverty-relief features, the VAT is seen as a successful revenue-raising tool.

Source: Le, 2003

There is some disagreement in the literature about whether and how to include the informal economy in the VAT base. Le (2003) observes that VAT tends to impose high compliance costs on small traders who generally do not have sufficient resources to keep proper records of their transactions and to comply with accounting rules. Although the number of small traders is large, including them in the tax net would produce limited revenue and create high administration costs. ${ }^{27}$

\subsubsection{Gender Bias in Commodity Taxes}

Commodity taxes such as VAT alter relative prices between taxed and untaxed goods. Gender biases in such taxes tend to be implicit rather than explicit. Elson (1999) and 
others point out that gender biases can result from women's differential consumption patterns. Although the exact nature of these patterns must be discerned in a specific country context, generally it has been found that women tend to consume goods and services that benefit family health, education and nutrition, while men consume more of their income on personal items. Thus, women may bear a disproportionately larger burden of indirection taxation. At the same time, Ingrid Palmer (1995) argues that the exemption of a range of essentials can turn a VAT into a modestly progressive tax. Since men and women partly purchase and produce different goods and services, she suggests that VAT exemptions can be used as a policy instrument to advance gender equity.

Commodity taxes also alter relative prices between the paid and the unpaid care economy and in so doing affect the distribution of work between them. This distribution has clear gender implications. ${ }^{28}$

The literature review found two studies that examine the gendered effects of indirect taxation. Smith (2000) provided evidence showing the VAT burden on South African households at different levels of income who consume the same commodity basket. His analysis showed that expenditure on VAT as a proportion of both total taxes paid and annual income is highest for the lowest income household and becomes lower as household income rises. The South African VAT does give special consideration to the distributional impact of the tax. It zero rates certain foodstuffs, including brown bread, maize meal, dried beans, milk powder, rice, vegetables and fruit. Some goods that are important for the poor, such as paraffin, which is widely used by poor women for cooking, have been zero rated in recent years, and the South Africa's Women's Budget Initiative can claim that it contributed to this change. Poor women bear more of the burden of indirect taxes, both because they are poor and because of gender differentials in consumption patterns.

The second study examined the effect of indirect taxes on women-owned businesses. Van Staveren and Akram-Lodhi (2003) explore the effect of VAT in Vietnam on women's enterprises. Because female-owned enterprises have a different input cost structure than do male-owned enterprises, the VAT places a relatively higher burden on female-owned businesses than male-owned businesses because it increases their total costs and lowers their overall profits.

Female entrepreneurs have three types of input costs: labour, capital and materials. On the labour side, female entrepreneurs utilise less paid labour and less unpaid household labour than do male entrepreneurs as a result of gender stereotyping which structures the division of household responsibilities. Value-added tax is a proportion of the estimated value added that is generated by the enterprise. When male-operated household enterprises have more inputs of unpaid (female) household labour, there is an uncosted 'invisible' input into the production process that generates value added which will affect the calculation of VAT. Van Staveren and Akram-Lodhi conclude that gender inequality is not a function of the absolute amount of VAT that is payable, 
but rather a function of the gender division of labour in which female-operated enterprises have less access to unpaid household labour and lower levels of value added and which therefore results in female entrepreneurs paying a relatively higher proportion of their total earnings as tax.

On the capital side, women entrepreneurs face higher capital costs than do male entrepreneurs, in part because of credit market imperfections in Vietnam, which reduces their earnings. The Vietnamese government calculates VAT payments on 'reasonable' costs of capital, which is likely to proxy the market interest rate for loans. Female entrepreneurs pay higher interest rates than the market rate, so their VAT payments are likely to be higher than those of male entrepreneurs.

On the material input side, Van Staveren and Akram-Lodhi note that industrial and occupational sex segregation influences the burden of VAT payments. Womenowned enterprises are more likely to be in the trade sector, while male entrepreneurs are more likely to be in the production sector. Female entrepreneurs are, therefore, more likely to face the 10 per cent VAT levy, while male entrepreneurs pay the reduced VAT rate of five per cent. Moreover, the authors note that the food and beverages sub-sector, where women predominate, is in the 20 per cent VAT band and this rate is applied to food stalls in markets and on the streets. Thus, profit rates for female entrepreneurs may be diminished by the higher rates of tax applied to women in this sector.

The Vietnamese VAT contains 27 categories of exemption, including one for businesses below a threshold defined as 'the minimum level of business turnover minus a reasonable cost of business operation'. Many female-operated businesses fall below this threshold, and in principle they are exempted from VAT. However, exemptions are only granted to businesses that are registered and the registration rate for business owners is lower for women than for men. Thus, Van Staveren and Akram-Lodhi conclude: 'Non-registration by female-owned SMEs will considerably reduce the net earnings of an enterprise because they will be paying tax on higher priced inputs for which no redemption of VAT payments on inputs will be available' (Van Staveren and Akram-Lodhi, 2003, p. 26).

\subsection{Corporate Income Taxes}

Developed and developing countries generally impose an income tax on the income of business entities which are legally organised as corporations. There is a great deal of controversy in tax theory regarding corporate taxation since technically corporations are conduits for shareholders and corporate income is passed on to shareholders as dividends or as increased stock value. A corporate income tax means that the same income is taxed twice - both as personal income of the individual shareholder and as corporate income. Despite the 'double taxation' argument, corporate taxes continue 
to be applied because they produce significant revenues for governments which would be difficult to replace without a shift in tax burden to some other sector. In many countries, reductions in corporate tax rates have resulted in a shift of the tax burden from businesses to individuals. In South Africa, for instance, Hartzenberg (1996) and Smith (2000) report that there has been a continuing shift from company to personal tax. A traditional concern with regard to the corporate tax, particularly if there are high corporate rates, is the possible negative effect on business investment, although there is debate in the literature on the magnitude of the effect. ${ }^{29}$

A particular issue for all countries in open, globalised economies, and especially for developing countries which desperately need tax revenues but want also to attract foreign investment, is taxation of multinational corporations. In tax policy, there is general agreement that corporations should not be taxed by multiple jurisdictions on the same income, but there is no agreement as to whether corporate income should be allocated for tax purposes according to 'source' or 'residence'. The former allocates income to where it is produced; the second allocates income to where the entity has its residence or domicile.

Grunberg (1998) notes that the question of how to tax foreign income poses a trade-off between equity and revenue objectives. Adopting a residence principle is best for raising revenue: foreign income is treated as domestic income and taken into account in calculating the applicable tax rate. In practice, foreign income is difficult to track because of difficulties in decoding foreign tax documents, lack of co-operation at the operational level, legal challenges and competitive behaviour among countries. Hence, the alternative, the source principle, is often adopted, mostly for corporate taxation. So Treasuries try to make up the shortfall caused by the difficulty of collecting corporate taxes by increasing taxes on immobile factors such as land and labour (e.g. through payroll taxes).

Another issue is that there are many ways that multinational corporations allocate revenues and costs (transfer pricing) in order to minimise their total tax payments to all jurisdictions; this can be particularly challenging for local and national governments. This is particularly true in countries where capital markets have been liberalised and corporate investment can easily be moved to other countries. In the corporate tax, policymakers face most clearly the dilemma of balancing the need for short-term revenue to fund services which are needed for social and economic development against the need for capital investment which is also needed for economic growth.

\subsubsection{Gender Bias in Corporate Income Taxes}

Since corporate taxes apply to legal entities, they tend not to contain explicit gender bias, but an implicit gender bias is possible, depending on the incidence and behavioural effects of corporate taxation. Preferential tax treatment of different industries may affect men and women's employment and/or consumption differently. For instance, 
a differential tax on mining may affect men's employment more than women's as men predominate in that industry.

Gender issues may also be reflected in the distribution of the tax burden between corporate taxes and individual taxes, and in the overall level of taxes, if reductions in tax rates mean reductions in services on which women depend more than men. The literature on corporate taxation concludes that corporate taxes are borne by both the owners of capital and by consumers; there has been no attempt to tie these effects to gendered outcomes.

Only one study in this review discussed the gender dimensions of corporate income taxes. Smith (2000) notes that in principle women could benefit in two ways from increased investment that is associated with reductions in company taxes. They could presumably share in the profits resulting from these investments; however, in South Africa the majority of shareholders of large companies (which receive the greatest benefit from the reduction of corporate taxation) are men, so women may not be direct beneficiaries from reduced corporate taxes. Second, women could potentially benefit if corporate tax relief encourages private sector investment that creates employment. However, Smith observes that private sector investment in South Africa has been primarily in capital-intensive industries such as IT, energy and oil, in which employment is dominated by men.

In other countries, foreign direct investment (as a result of tax breaks for multinational corporations) has been associated with increased employment for women, especially in light manufacturing industries and in services. There is considerable debate, however, about the quality of these jobs and the long-term sustainability of this type of employment for women.

\subsection{The Tobin Tax Proposal ${ }^{30}$}

The Tobin tax, originally proposed by Nobel Laureate James Tobin, seeks to reduce volatility in the global economy by imposing a small international tax on foreign exchange transactions. There are now a variety of proposals for Tobin-type taxes, which many argue could be a significant source of revenue that could be used for development purposes (Palley, 2001; Haq et al., 1996). According to some estimates, a Tobin tax has the potential to raise a large amount of revenue. For instance, using 1995 currency transactions figures, Felix and Sau (1996) estimate the global revenues from a Tobin tax of 0.1 per cent to be in the range of $\$ 148-180$ billion. If the tax were set at 0.05 per cent, the revenue estimate increases to $\$ 90-97$ billion.

Many consider revenues from Tobin taxes as an attractive policy alternative given the widely acknowledged problem of tax competition (Tanzi, 1996; OECD, 2001) which has contributed to an erosion of national tax bases and the shift from direct to indirect taxation (Rodrik, 1997). It is argued that a Tobin tax would be relatively pro- 
gressive in incidence, because the burden would fall predominantly on higher income individuals and on corporations. The amount of revenue raised would also depend on the extent to which the tax reduces currency speculation. If the tax has little impact, the revenues will be relatively larger; if the tax has a large impact, the revenues will be relatively smaller. However, many argue the tax is justified (Palley, 2001; Baker, 2002; Pollin et al., 1999).

The literature on Tobin taxes has discussed problems of enforcement, avoidance and evasion that plague national tax systems. Critics argue that these problems make the Tobin tax infeasible. Advocates respond that evasion and avoidance should not be the determining factor in determining the feasibility of such a tax, because every tax system is subject to some evasion and avoidance. The extent of such behaviour is always a concern. Other factors relevant to the implementation of a Tobin tax include the amount of needed revenue that the tax raises and the behaviour it discourages. Palley (1991) argues: 'This is the test that should be applied to the Tobin tax - just as it should for all tax systems - and on this test the Tobin tax scores well.'

Beyond these issues is a question about the nature of regulation in a dynamic global economy. Critics of the Tobin tax argue that financial markets will innovate to avoid it. Advocates respond that this may be true but, again, that this does not mean that a Tobin tax is unwarranted. There are many ways to regulate undesirable behaviour of firms.

\subsubsection{Gender and Tobin Taxes}

It has been suggested that a portion of the revenues raised by a Tobin tax could be awarded to governments for the design of gender-equitable social insurance and social protection systems. A Tobin tax would also potentially reduce market volatility caused by movements in speculative, short-term capital flows - which has disproportionately negative impacts on women (see Çağatay, 2003).

\subsection{Trade Taxes}

Taxes on foreign trade take the form of import and/or export duties. They are similar to broad-based domestic consumption and excise taxes. They typically apply to a broader range of commodities than excise taxes but with different rates. Trade taxes (import tariffs and export taxes) are important policy instruments for resource allocation purposes (i.e. protection for import-competing sectors) and for revenues. Historically, developing countries have relied heavily on trade taxes because other tax bases and tax administration capability are weak, and trade taxes are relatively easy to assess and enforce. Though the relative weight of trade taxes has declined over the last two decades because of trade liberalisation policies, trade taxes continue to be an important source of revenue for the governments of developing countries, especially in lowincome countries. The share of total trade taxes in total tax revenue between the 
1970s and 1998 averaged 36 per cent for low-income countries, 29 per cent for lower middle-income countries, 19 per cent for upper middle-income countries, and only 3 per cent for high-income countries (see Table 3.2 above).

\subsubsection{Gender Bias in Trade Taxes}

There are very few studies of the impact of gender bias in trade taxes. One study, produced by the South Africa Women's Budget Initiative, examines the gender dimensions of customs and excise taxes. By analysing a range of regional and multilateral free trade agreements, Tanya Goldman (2000) explores the impact that South Africa's import and excise taxes are likely to have upon sectors with concentrations of women. The paper delineates the individual trade agreements and the potential repercussions that adoption could have upon women, particularly if the agreements are implemented suddenly. In recent years, South African trade policy has shifted towards export-led growth. The abrupt rescinding of earlier tariffs has forced many low-skilled industries (where women are disproportionately concentrated) to rapidly become much more competitive.

Goldman identifies three ways in which tariffs affect women: as workers in sectors of the economy where goods are imported and exported (e.g. clothing and agriculture); as consumers of imported goods (e.g. medicines); and as traders in export goods. In South Africa, women predominate in labour-intensive industries, such as clothing and textiles, which have been hard hit by import tariff reductions. The reduction of import tariffs on basic goods such as clothing and food, resulting in lower prices, would be a benefit for poor women. These benefits, however, must be weighed against job losses in the affected industries and the spillover effects to the overall economy. Stephanie Seguino has pointed out that tariff cuts that lead to job losses can lead to a fall in wages in non-protected sectors as workers from protected sectors seek employment. ${ }^{31}$ Further, depending on the multiplier effects, economic downturns can set in, causing widespread job losses and cuts in public expenditure.

Rao (1999) has examined trade taxes and human development in developing countries. Although he does not explicitly consider gender issues, one can draw at least one gender implication from his analysis. Rao demonstrates empirically that trade taxes (as a percentage of trade volume) have a positive effect on current government expenditure. Reductions in import taxes, on the other hand, were associated with decreases in public sector investment in infrastructure and education, which in turn could have negative implications for women's time allocations and expenditures.

\subsection{Tax Reform and Gender}

As noted in Section 3, tax reform can have gender implications. First, the emphasis on tax simplification in both income and consumption taxes leads to policy recommendations to limit deductions and exemptions. Such limits have equity implications from 
both a class and a gender perspective. In personal income tax, the restriction of certain deductions and exemptions which provide tax relief to women, for example childcare deductions, dependent exemptions or deductions for insurance and pension contributions, may create gender inequity. In consumption taxes, the elimination of exemptions on products which are primarily consumed by women or are of primary importance to women could create gender bias. And in both types of taxes, base broadening which imposes a higher burden on the poor will also create higher burdens for women who are disproportionately poor in developed countries, and primarily poor in developing countries.

The literature on tax reform efforts bears out some of these conclusions and also notes other effects. Reform efforts in Japan's PIT in 1989 did indeed exacerbate gender inequality. Shibata (1994) showed that changes to the rate and deduction structure discouraged married women from entering paid employment. At the same time, some reform efforts in European countries, including France, the Netherlands and the UK, have sought to reduce explicit gender bias in personal income tax codes. Reforms in the US reduced the marriage penalty and eliminated other forms of gender bias in exemptions and deductions (Nelson, 1996). Some developing countries have also taken explicit measures to reduce gender biases in personal income taxes. Malaysia, for example, changed its tax system in 1991 from one in which the income of married women was attributed to their husbands unless she elected for separate assessment to a system in which husbands and wives are treated as separate taxable units. In 1995, South Africa unified rates schedules for married persons, single persons and married women, reducing the rates for the two latter categories.

Smith (2000) analysed the gender implications of South Africa's efforts to reform direct and indirect taxes. In 1994, the Katz Commission was appointed to review the tax system and make recommendations for improvement. The commission placed great emphasis on equity as a key principle, along with concerns about poverty and income inequality. Some of the changes that have taken place since 1994 eliminate formal discrimination based on gender, including the introduction of a unified income tax rate structure for individuals and the removal of the distinction between married and unmarried households; tax relief has also been given to low- and middle-income taxpayers through adjustments to tax rates and income brackets.

Smith points out, however, that these changes have not eliminated all forms of discrimination against women. The new system still discriminates against households with only one income earner which pay over four times as much income tax as households with two income earners and the same income and number of dependents as the one-earner household. Gender bias also continues to exist in the way that tax deductions are permitted in the new system. Allowances for travel and accommodation are biased toward men. Although reforms in the PIT closed some of the most egregious gaps between women and men, it did not close gaps between rich and poor individuals 
and rich and poor households. Since women in South Africa predominate in informal employment or work in low-paid formal sector jobs, relatively few women have benefited from a more progressive income tax system. More recent reforms seeking to give relief to low-income individual earners may, however, correct these biases.

Smith also evaluated the impact of reforms in consumption taxes on women and the poor. He noted that VAT contains exemptions for certain foods and basic goods and services consumed by low-income people, but that the tax reform commission rejected further extensions of zero rating, fearing substantial revenue losses.

As Esim (2000) notes, the gender implications of tax reform require further research. While the links between gender equality and personal income taxes are better understood, the implications of indirect and corporate taxes still need to be investigated. More country case studies need to be analysed to give a better picture of the direction of the reforms and how they influence women.

\subsection{User Charges}

As noted in Section 3, as part of fiscal decentralisation, sub-national levels of government are increasingly expected to rely on own-source revenues. Property taxes and user fees are the most common local source of revenue. Since the review did not find any articles on the gender dimensions of property taxes, we restrict our discussion to user fees.

User fees are charges for services or products provided by governments. Following the recommendations of the World Bank and the International Monetary Fund in the past two decades, user financing of basic social services have become common practice in many developing countries, and user fees have become an alternative to tax-based financing for public services. A critical debate in developing countries centres on whether user charges should be imposed on basic public services like water, electricity, health and education. User fees that are more commonly accepted are for selected locally provided optional services such as public transportation charges and parks and recreation.

Proponents of user fees argue that governments need revenues and that charging users for services is an efficient way to raise money for these services. They also argue that user charges may be an effective method of reducing consumption of scarce resources. This argument is based on the idea that user fees allow governments to impose the cost of services on the citizens who use them, and allow market forces to set an economically efficient level of services. Additionally, proponents argue that user fees are especially appropriate when state or local governments provide services that also are provided by the private sector, particularly if they are not core government services.

Opponents of user fees argue that there is growing evidence of the equity losses: reduced utilisation of services and negative effects on wellbeing and health resulting 
from the introduction of user fees. In most cases user fees have the unintended effect of decreasing access to basic services (education and health, in particular) by the poor. Opponents also claim that user fees for health and education do not appear to generate adequate revenue to support even basic provision of these services. National user fee systems have generated an average of only around 5 per cent of total recurrent health system expenditures, gross of administrative costs. The cost recovery levels for health services range from 0.5 per cent in Burkina Faso (1981) and Guinea Bissau (1988) to 9 per cent in Lesotho (1991-92) and Mozambique (1985) (Reddy and Vandemoortele, 1996).

Palmer (1995) notes that user charges can be highly regressive, as they constitute a tax on services which were formerly often free at the point of delivery. They have the effect of transferring the costs of providing these services to women in the unpaid care economy. User fees also frequently exacerbate discrimination against girls with respect to utilisation of healthcare and education. One way to mitigate this is to apply user charges to services where gender disparities would not be significantly worsened by attaching a price tag. Another way is through exemptions.

In some countries, governments allow exemptions for the poor from user fees. This can be done in two ways. One is through direct or individual targeting. This type of targeting identifies poor individuals and provides them with services for which others are expected to pay at reduced or no cost. The second is indirect or characteristic targeting. Under this approach, the focus is not on particular individuals but on general characteristics of the programme or its clients. An example of this is the exemption of particular services important to the poor, for instance, immunisation or maternal and child health programmes. The services in question are provided free of charge to rich as well as to poor people, but the poor are expected to benefit most because they are the primary service users and/or gain the most from the services.

Two criteria have been established to evaluate the effectiveness of a targeting programme. One concerns the percentage of the poor population reached by the programme: a programme that fails to cover a large percentage of the poor population is commonly said to suffer from under-coverage or from a large exclusion error. The second criterion is related to the percentage of the programme's benefits that go to people who are not poor. A programme that is designed to serve the poor, but that is used primarily by the non-poor, is considered to have a major leakage problem or large inclusion error.

Vandemoortele (2000) cites a study that found that exemptions based on the ability to pay are extremely uncommon in practice. Exemption schemes for health in sub-Saharan Africa are not only rare, but they are also implemented in informal and ad hoc ways. The decision to exempt is often left to the discretion of local service providers, while the characteristics of the poor are generally not clearly defined. Further, if financial incentives or staff performance appraisals are linked to the 
criterion of cost recovery, as they have been in many countries, then there can be a direct trade-off between the goal of revenue collection and that of reducing the negative impact of user fees on the poor.

Nanda's (2002) comprehensive review of the literature on the gender dimensions of user fees in the health sector in Africa during the mid-1990s brings the above discussion into sharp relief. She notes that a gender-based analysis of user fees should look at two aspects: the differential impact of user fees on utilisation of healthcare between men and women; and how user fees affect women's utilisation of healthcare for themselves. The limited nature of the data makes it impossible to answer the first question, so her review focused on studies that examine the second issue. Nanda cites studies suggesting that the introduction of user fees is often followed by a subsequent fall in service utilisation. The magnitude of this drop is often greater and occurs over a longer period for the poor. In Kenya, the introduction of user fees (amounting to half a day's pay for a poor person) in government outpatient health facilities led to a dramatic reduction in utilisation of STD services by both men and women, but the fall was significantly greater for women. Fewer women than men utilised the services prior to the introduction of user fees. Nine months after their introduction, the fees were revoked and women's utilisation rose to a greater level than the pre-fee levels. Use of maternal healthcare services was also affected when fees were introduced or revoked. Although some basic antenatal care and family planning services are exempt from user fees in some countries, there was little incentive for providers to apply exemptions, and abuses and inconsistencies in application were widespread.

The World Bank has recently acknowledged that user fee exemption systems seldom work in practice. In a letter to a member of the US Congress dated 29 September 1999, World Bank Vice-President Eduardo Doryan said: 'Experience in and since the 1980s has shown that the poor have not been effectively protected in many cases [from user fees]. Planning for new or higher fees has frequently outstripped adequate protection and implementation of exemptions and safety nets.' As a result, the World Bank now accepts that user fees should not be imposed for basic services such as education and health (World Bank, 2003). 